\title{
RESEARCH PAPER \\ Mineral salts and growth regulators for micropropagation of Laelia halbingeriana Salazar \& Soto Arenas
}

\section{Rosalía García-González', José R. Enríquez-del Valle, Gerardo Rodríguez- Ortiz $^{1}$, Gisela V. Campos-Angeles ${ }^{1}$, Eduardo A. Pérez-García ${ }^{2}$, and Judith Ruiz-Luna ${ }^{1}$ \\ ${ }^{1}$ Instituto Tecnológico del Valle de Oaxaca (ITVO), División de Estudios de Posgrado e Investigación.} Domicilio conocido, Nazareno Xoxocotlán, Oaxaca. México. C.P. 71233.

${ }^{2}$ Universidad Nacional Autónoma de México, Facultad de Ciencias, Departamento de Ecología y Recursos Naturales. México 04510, D. F., México.

\begin{abstract}
R. García-González, J.R. Enríquez-del Valle, G. Rodríguez-Ortiz, G.V. Campos-Angeles, E.A. Pérez-García, and J. Ruiz-Luna. 2020. Mineral salts and growth regulators for micropropagation of Laelia halbingeriana Salazar \& Soto Arenas. Int. J. Agric. Nat. Resour. 105-116. Laelia halbingeriana Salazar \& Soto Arenas is a wild epiphytic orchid endemic to Oaxaca, Mexico, that is collected with no plans for its management or conservation. The objective of this study was to propagate and evaluate the in vitro development of this species in the culture media with a variety of mineral salts and growth regulators. Groups of three plants, 1.2 to $1.4 \mathrm{~cm}$ tall, were established in receptacles with culture medium containing $30 \mathrm{~g}$ $\mathrm{L}^{-1}$ sucrose, $1 \mathrm{mg} \mathrm{L}^{-1}$ thiamine, $100 \mathrm{mg} \mathrm{L}^{-1}$ inositol and $0.5 \mathrm{mg} \mathrm{L}^{-1}$ benzyl aminopurine (BAP). Proportions of Murashige and Skoog (1962) or Knudson (1946) mineral salts were varied (100, 66 and 33\%). The growth regulators indoleacetic acid (IAA) and kinetin (Kin) were used at various concentrations $\left(0.5+0.5 \mathrm{mg} \mathrm{L}^{-1}, 1+1 \mathrm{mg} \mathrm{L}^{-1}\right.$ and $\left.2+2 \mathrm{mg} \mathrm{L}^{-1}\right)$. $\mathrm{pH}$ was adjusted to 5.8 , and $5.5 \mathrm{~g} \mathrm{~L}^{-1}$ agar was added. After 120 days of incubation, the plants that were cultivated in $66 \%$ and $100 \%$ Knudson media were $2.1 \mathrm{~cm}$ tall and had 4.8 roots, while the plants in $100 \%$ Murashige and Skoog media were $1.5 \mathrm{~cm}$ tall and had 2.5 roots. For 120 days, the plants had a logarithmic trend in vertical growth $\left(R^{2} \geq 0.96\right)$. Several plant characteristics were evaluated simultaneously using a cluster analysis, which found that the best culture medium for Laelia halbingeriana development contains $100 \%$ Knudson mineral salts, $0.5 \mathrm{mg} \mathrm{L}^{-1} \mathrm{BAP}, 0.5 \mathrm{mg} \mathrm{L}^{-1}$ IAA, and $0.5 \mathrm{mg} \mathrm{L}^{-1} \mathrm{KIN}$.
\end{abstract}

Keywords: Growth regulators, mineral salts, plant development, propagation.

\section{Introduction}

Laelia halbingeriana (Salazar \& Soto Arenas) is a wild epiphytic species of the Orchidaceae

Received Feb 26, 2019. Accepted May 11, 2020. Corresponding author: grodriguez.itvo@yahoo.com family endemic to the Biosphere TehuacánCuicatlán Reserve, a protected natural area in the state of Oaxaca. The plant grows adhered to the trunks and branches of Quercus spp. The plant is an attractive ornamental and thus, large quantities of this species are collected, and wild 
populations are dwindling (Salazar et al., 2006). This species should be considered "subject to special protection" because its distribution area of less than $5,000 \mathrm{~km}^{2}$ is severely fragmented and reduced to approximately $1,800 \mathrm{~km}^{2}$ (Salazar et al., 2014). Development of in vitro propagation and cultivation in greenhouses and nurseries has been suggested as an alternative to collecting wild orchids. The objectives of conservation and commercial production can be attained within these projects. Procedures for propagation of several species have been described. Seed germination of Oncidium stramineum Lindl and plant development in the culture medium containing MS mineral salts (Murashige \& Skoog, 1962; Flores-Escobar et al., 2008) have been evaluated. Development of Laelia speciosa (Kunth) Schltr protocorms and seedlings was evaluated in MS culture media with various concentrations of growth regulators (GR), naphthaleneacetic acid, (NAA) and benzyl aminopurine (BAP) (Avila-Díaz et al., 2010).

Orchids grow slowly, and in the wild, it takes approximately seven years to flower after seed germination. On the other hand, if the plants are cultured in a greenhouse nursery, they can flower in four to six years depending on the species. Laelia halbingeriana fruits contain thousands of viable seeds that germinate under optimal conditions; however, there is no information on the time of development from seed germination to reproductive age (Hágsater et al., 2006). It is possible to achieve asymbiotic germination of the seeds and in vitro development of $L$. halbingeriana seedlings (Heredia-Rincón et al., 2009). The goal of the present work was to evaluate the components of the in vitro culture medium, in particular the concentrations of mineral salts, MS salts and GR that contribute to optimization of the growth and development of this species.

For in vitro propagation of Oncidium bifolium Sims, MS mineral salts diluted to a half of the full concentration were more beneficial to the plant growth than the full concentration (Dalzotto,
2013). Good plant development has been achieved in culture media with other mineral salt formulations, such as Knudson (KN), Hutner, Dalla Rosa, Phytamax, and Morel, which have lower total ion concentrations than that in the full-strength MS (Hossain et al., 2009). Moreover, various concentrations of GR were evaluated for in vitro propagation of Euchile mariae (Ames) Withner and it was found that the plants grown in culture media with BAP developed more protocormlike bodies, PLBs (Suárez-Quijada et al., 2007). Lozano-Rodríguez et al., (2015), cultured Vanilla planifolia Jacks ex Andrews in vitro and reported that $8.88 \mu \mathrm{M}$ BAP promoted the formation and development of adventitious shoots. Thus, this study aimed to evaluate the in vitro development and growth of Laelia halbingeriana established in the culture media with variable composition and concentrations of mineral salts and GR. Our hypothesis was that the concentrations of mineral salts and GR have different effects on Laelia halbingeriana development and growth.

\section{Materials and methods}

\section{Handling of experimental material}

Plants of Laelia halbingeriana were collected in the La Cañada region, Oaxaca, Mexico, in the areas of wild vegetation affected by construction of power transmission lines. The plants were established in the botanical garden of the Technological Institute of the Valley of Oaxaca; since 2009, these plants have developed flowers and fruits. Since 2009, seed germination and in vitro propagation have been carried out. This study was conducted in the laboratory of plant tissue culture of the Instituto Tecnológico del Valle de Oaxaca, Mexico, located at $17^{\circ} 04^{\prime} \mathrm{N}$ and $96^{\circ} 43^{\prime} \mathrm{W}$ at an altitude of $1,519 \mathrm{~m}$ (INEGI, 2004). The plants of various sizes ( 0.5 to $4 \mathrm{~cm}$ tall) were grown in an aseptic gelatinous culture medium, which contained MS mineral salts, 1 $\mathrm{mg} \mathrm{L}^{-1}$ thiamine- $\mathrm{HCl}, 25 \mathrm{~g} \mathrm{~L}^{-1}$ sucrose, $0.5 \mathrm{mg}$ $\mathrm{L}^{-1} \mathrm{BAP}$, and $5.7 \mathrm{~g} \mathrm{~L}^{-1}$ agar. 
For the experiment, the plants with similar characteristics were selected based on height (from 1.2 to $1.3 \mathrm{~cm}$ ) and number of leaves. Aseptic conditions were achieved with a horizontal laminar flow chamber (Forma Scientific, model 1839, Marietta, OH-USA), sterilized dissection tools, forceps, scalpels and $10 \times 100 \mathrm{~mm}$ glass Petri dishes; the selected plants were transferred to $145 \mathrm{~cm}^{3}$ glass receptacles that contained $20 \mathrm{~mL}$ of culture medium containing $1 \mathrm{mg} \mathrm{L}^{-1}$ thiamine, $30 \mathrm{~g} \mathrm{~L}^{-1}$ sucrose, $100 \mathrm{mg} \mathrm{L}^{-1}$ inositol, and $0.5 \mathrm{mg}$ $\mathrm{L}^{-1} \mathrm{BAP}$. The following conditions were varied: 1) factor formulations of mineral salts, MS or $\mathrm{KN}$; each formulation was used at three different concentrations ( $\mathrm{MS}=100,66$ and $33 \%$ and $\mathrm{KN}=100$, 66 and 33\%) and 2) factor growth regulator, GR, at three levels of the mixtures (GRM1 $=0.5 \mathrm{mg}$ $\mathrm{L}^{-1} \mathrm{BAP}+0.5 \mathrm{mg} \mathrm{L}^{-1} \mathrm{KIN}+0.5 \mathrm{mg} \mathrm{L}^{-1} \mathrm{IAA}$; GRM2 $=0.5 \mathrm{mg} \mathrm{L}^{-1} \mathrm{BAP}+1 \mathrm{mg} \mathrm{L}^{-1} \mathrm{KIN}+1$ $\mathrm{mg} \mathrm{L}^{-1} \mathrm{IAA}$; and $\mathrm{GRM} 3=0.5 \mathrm{mg} \mathrm{L}^{-1} \mathrm{BAP}+2$ $\left.m g L^{-1} \mathrm{KIN}+2 \mathrm{mg} \mathrm{L}^{-1} \mathrm{IAA}\right) \cdot \mathrm{pH}$ of the culture media was determined with a Conductronic $\mathrm{pH}$ 120 potentiometer and adjusted to 5.8 with $1 \mathrm{~N}$ $\mathrm{HCl}$ and $\mathrm{NaOH}$ before the addition of $5.7 \mathrm{~g} \mathrm{~L}^{-1}$ agar. The formulations of the GR mixtures were investigated during four years of in vitro cultivation of Laelia halbingeriana during investigation of the conditions of the minimal proliferation of propagules; formulations used in the present work enhanced growth of the propagules. All substances were weighed with an analytical balance (ADAM EQUIPMENT CO., LTD.) with total capacity of $300 \mathrm{~g}$ and accuracy of $0.1 \mathrm{mg}$. Agar was dissolved by heating and shaking on an electric hotplate (CIMAREC, Barnstead Thermolyne). Culture medium $(20 \mathrm{~mL})$ was placed into each $145 \mathrm{~cm}^{3}$ receptacle, which was closed with a polypropylene stopper and sterilized for $17 \mathrm{~min}$ in an autoclave (AESA MOD. CV 300) at $121{ }^{\circ} \mathrm{C}$ and pressure of $1.2 \mathrm{~kg} \mathrm{~cm}^{-2}$. Under the aseptic conditions, the plants were extracted from their initial culture medium and nine plants were distributed per receptacle for treatment with the variants of the culture medium. The receptacles were covered, sealed with adhering polyethylene and transferred to the incubation area where they were incubated for 120 days exposed to diffused solar radiation and white fluorescent illumination at intensity of 2,000 lux $\left(37 \mu \mathrm{mol} \mathrm{s}^{-1} \mathrm{~m}^{-2}\right)$ at photoperiods of $16 \mathrm{~h}$ and $8 \mathrm{~h}$ darkness and temperature from 16 to $28^{\circ} \mathrm{C}$.

\section{Management and data analysis}

The experiment was conducted under a completely randomized design with a $6 \times 3$ factorial array of the treatments; the factor mineral salt type and dilution were used at six levels and the factor GR were used at three levels. The experimental unit included a single receptacle containing nine plants; however, the data were collected only from three plants; an average was calculated for each characteristic. There was a total of 11 replicates per treatment.

At the beginning of the experiment and every two months thereafter, height $(\mathrm{cm})$ was measured with an electronic Vernier caliper and recorded. The number of leaves, roots, shoots and new plants was quantified. The rates of monthly increments were calculated based on the data on the number of leaves, shoots, and roots on the initial date and after 120 days of incubation. The data on the initial and last dates and the increment rates of each variable were subjected to an analysis of variance and comparison of the means (Tukey; $\alpha=0.05$ ) and to cluster analysis. The data on plant height in each treatment were analyzed as a function of time (four months) by regression. The logarithmic model $P H=\mathrm{b}^{0}(\text { Age })^{\mathrm{bl}}$ provided the best fit.

The variables, including height, number of leaves, number of roots, and number of shoots, were analyzed simultaneously with cluster analysis. The Statistical Analysis System software (SAS Institute Inc. 2004) was used for routine types of analysis including PROC ANOVA, GLM, NLIN and CLUSTER procedures. 


\section{Results}

After 120 days of incubation (February to June 2017), the analysis of variance (Table 1) showed that the evaluated GR mixtures had no significant effect $(P>0.05)$ on height, shoot proliferation, leaves and roots. The types and concentrations of mineral salts (MS) had highly significant effects $(P \leq 0.01)$ on plant height at four months of incubation (PHJ), monthly growth rate in height (MGRH), number of shoots in the fourth month (NBJ), monthly rate of increase in the number of leaves (MGRL), number of roots in the fourth month (NRJ) and monthly rate of increase in the number of roots (MGRR). The interaction of MGR $\times$ MS had significant effects $(\mathrm{P}<0.05)$ on plant height in the fourth month of incubation (NBJ) and number of roots in the fourth month (NRJ) and highly significant effects $(\mathrm{P} \leq 0.01)$ on the monthly rate of increase in the number of leaves (MGRL) and monthly rate of increase in the number of roots (MGRR).

The results were grouped as a function of the principal factors, including Msalts and mixtures of
GR (Table 2); at the beginning of the experiment (February), the plants under various conditions had statistically similar values in all variables: PHF, NSF, NLF, and NRF. In June, after 120 days, significant differences were observed (Tukey, 0.05 ) in all variables (Figure 1).

The plants established in the culture media with mineral salts $\mathrm{KN}-100$ and $\mathrm{KN}-66$ had initial height of $1.27 \mathrm{~cm}$ and had an increase in height by $0.22 \mathrm{~cm} / \mathrm{month}$; thus, after 120 days, these plants were $2.15 \mathrm{~cm}$ tall. These values were significantly higher $(P<0.05)$ than those detected in the plants established in MS-100, MS-66 and MS-33 (0.09 to $0.14 \mathrm{~cm} /$ month and 1.57 to 1.74 $\mathrm{cm}$ total height) (Tables 2 and 3). The number of shoots (NSJ) and the monthly rate of increase in the number of shoots, MGRS, were different due to the effect of the mineral salts since the plants established in the culture medium with $\mathrm{KN}-100$ had 6.6 new shoots, NSJ, which was significantly higher $(P<0.05)$ than $1.83 \mathrm{NSJ}$ formed on the plants grown in the MS-100 culture medium. The plants established in KN-100 and KN-66 formed 1.10 and 1.21 roots/month, respectively.

Table 1. Summary of analysis of variance (mean squares) of the variables of Laelia halbingeriana cultivated in vitro in various culture media containing varied mixtures of growth regulators and mineral salts and the interactions of the factors.

\begin{tabular}{lccccccc}
\hline SV & DF & PHF & PHJ & MGRH (cm/month) & NSF & NSJ & $\begin{array}{c}\text { MGRS (shoots/ } \\
\text { month) }\end{array}$ \\
\hline GRM & 2 & $0.03^{\text {ns }}$ & $0.19^{\text {ns }}$ & $0.005^{\text {ns }}$ & $0.08^{\text {ns }}$ & $0.22^{\text {ns }}$ & $0.007^{\text {ns }}$ \\
Msalts & 5 & $0.07^{*}$ & $2.13^{* *}$ & $0.08^{* *}$ & $0.01^{\text {ns }}$ & $112.38^{* *}$ & $6.91^{* *}$ \\
GRM $\times$ Msalts & 10 & $0.05^{*}$ & $0.21^{*}$ & $0.01^{\text {ns }}$ & $0.03^{\text {ns }}$ & $9.29^{\text {ns }}$ & $0.61^{*}$ \\
Error & 180 & 0.02 & 0.11 & 0.006 & 0.06 & 5.60 & 0.32 \\
Total & 197 & & & & & & MGRR (roots/month) \\
SV & DF & NLF & NLJ & MGRL (leaves/ & NRF & NRJ & \\
GRM & 2 & $0.71^{\text {ns }}$ & $0.89^{\text {ns }}$ & $0.03^{\text {ns }}$ & $0.39^{\text {ns }}$ & $7.32^{\text {ns }}$ & $0.27^{\text {ns }}$ \\
Msalts & 5 & $0.26^{\text {ns }}$ & $0.61^{\text {ns }}$ & $0.09^{* *}$ & $0.30^{\text {ns }}$ & $35.24^{* *}$ & $1.94^{* *}$ \\
GRM $\times$ Msalts & 10 & $0.62^{\text {ns }}$ & $1.14^{*}$ & $0.07^{* *}$ & $0.14^{\text {ns }}$ & $8.72^{*}$ & $0.49^{* *}$ \\
Error & 180 & 0.51 & 0.58 & 0.02 & 0.20 & 4.24 & 0.22 \\
Total & 197 & & & & & & \\
\hline
\end{tabular}

$\mathrm{SV}=$ source of variation, $\mathrm{GRM}=$ growth regulator mixtures, Msalts=mineral salts. $\mathrm{DF}=$ degrees of freedom. $\mathrm{PHF}=$ plant height in February, PHJ=plant height in June, MGR H, S, L, R= monthly rate of increase (in height, shoots, leaves and root), NSF=number of shoots in February, NSJ=number of shoots in June, NLF=number of leaves in February, NLJ=number of leaves in June, $\mathrm{NRF}=$ number of roots in February, and $\mathrm{NRJ}=$ number of roots in June. 
Table 2. Characteristics of Laelia halbingeriana plants established in culture media with various types and concentrations of mineral salts (Msalts) and growth regulators (GR).

\begin{tabular}{|c|c|c|c|c|c|c|}
\hline $\begin{array}{l}\text { Factor } \\
\text { Msalts }\end{array}$ & PHF (cm) & $\mathrm{PHJ}(\mathrm{cm})$ & MGRH (cm/month) & NSF & NSJ & $\begin{array}{c}\text { MGRS } \\
\text { (shoots/month) }\end{array}$ \\
\hline MS100 & $1.18 \pm 0.18^{\mathrm{a}}$ & $1.57 \pm 0.21^{\mathrm{c}}$ & $0.09 \pm 0.04^{\mathrm{c}}$ & $0.13 \pm 0.20^{\mathrm{a}}$ & $1.83 \pm 1.39^{\mathrm{c}}$ & $0.42 \pm 0.43^{\mathrm{c}}$ \\
\hline MS66 & $1.16 \pm 0.14^{\mathrm{a}}$ & $1.64 \pm 0.21^{\mathrm{c}}$ & $0.12 \pm 0.04^{\mathrm{c}}$ & $0.18 \pm 0.30^{\mathrm{a}}$ & $2.60 \pm 1.41^{\mathrm{bc}}$ & $0.60 \pm 0.32^{\mathrm{bc}}$ \\
\hline MS33 & $1.18 \pm 0.15^{\mathrm{a}}$ & $1.74 \pm 0.31^{\mathrm{bc}}$ & $0.14 \pm 0.06^{\mathrm{bc}}$ & $0.18 \pm 0.26^{\mathrm{a}}$ & $2.97 \pm 1.39^{\mathrm{bc}}$ & $0.69 \pm 0.34^{\mathrm{bc}}$ \\
\hline $\mathrm{KN} 100$ & $1.27 \pm 0.15^{\mathrm{a}}$ & $2.15 \pm 0.37^{\mathrm{a}}$ & $0.22 \pm 0.09^{\mathrm{a}}$ & $0.19 \pm 0.23^{\mathrm{a}}$ & $6.66 \pm 4.03^{\mathrm{a}}$ & $1.61 \pm 0.98^{\mathrm{a}}$ \\
\hline KN66 & $1.26 \pm 0.19^{\mathrm{a}}$ & $2.15 \pm 0.49^{\mathrm{a}}$ & $0.22 \pm 0.12^{\mathrm{a}}$ & $0.18 \pm 0.27^{\mathrm{a}}$ & $5.49 \pm 2.65^{\mathrm{a}}$ & $1.32 \pm 0.63^{\mathrm{a}}$ \\
\hline KN33 & $1.21 \pm 0.18^{\mathrm{a}}$ & $1.95 \pm 0.41^{\mathrm{ab}}$ & $0.18 \pm 0.09^{\mathrm{ab}}$ & $0.16 \pm 0.25^{\mathrm{a}}$ & $3.65 \pm 2.29^{b}$ & $0.87 \pm 0.55^{b}$ \\
\hline \multicolumn{7}{|l|}{ GRM } \\
\hline 1 & $1.24 \pm 0.17^{\mathrm{a}}$ & $1.93 \pm 0.44^{\mathrm{a}}$ & $0.17 \pm 0.10^{\mathrm{a}}$ & $0.15 \pm 0.24^{\mathrm{a}}$ & $3.80 \pm 2.46^{\mathrm{a}}$ & $0.91 \pm 0.61^{\mathrm{a}}$ \\
\hline 2 & $1.20 \pm 0.14^{\mathrm{a}}$ & $1.82 \pm 0.40^{\mathrm{a}}$ & $0.15 \pm 0.09^{\mathrm{a}}$ & $0.21 \pm 0.27^{\mathrm{a}}$ & $3.91 \pm 2.73^{\mathrm{a}}$ & $0.92 \pm 0.65^{\mathrm{a}}$ \\
\hline 3 & $1.19 \pm 0.19^{\mathrm{a}}$ & $1.85 \pm 0.40^{\mathrm{a}}$ & $0.16 \pm 0.08^{\mathrm{a}}$ & $0.15 \pm 0.24^{\mathrm{a}}$ & $3.89 \pm 3.47^{\mathrm{a}}$ & $0.93 \pm 0.85^{\mathrm{a}}$ \\
\hline $\begin{array}{l}\text { Factor } \\
\text { Msalts }\end{array}$ & NLF & NLJ & MGRL (leaves/month) & $\mathrm{NRF}$ & NRJ & $\begin{array}{c}\text { MGRR } \\
\text { (roots/month) }\end{array}$ \\
\hline MS100 & $4.05 \pm 0.78^{\mathrm{a}}$ & $5.61 \pm 1.01^{\mathrm{a}}$ & $0.39 \pm 0.18^{\mathrm{a}}$ & $0.19 \pm 0.18^{\mathrm{a}}$ & $2.51 \pm 1.25^{\mathrm{c}}$ & $0.58 \pm 0.29^{\mathrm{b}}$ \\
\hline MS66 & $4.10 \pm 0.77^{\mathrm{a}}$ & $5.74 \pm 0.83^{\mathrm{a}}$ & $0.41 \pm 0.19^{\mathrm{a}}$ & $0.33 \pm 0.39^{\mathrm{a}}$ & $3.14 \pm 1.43^{\mathrm{c}}$ & $0.70 \pm 0.35^{\mathrm{b}}$ \\
\hline MS33 & $4.10 \pm 0.62 \mathrm{a}$ & $5.74 \pm 0.65^{\mathrm{a}}$ & $0.41 \pm 0.13^{\mathrm{a}}$ & $0.43 \pm 0.51^{\mathrm{a}}$ & $3.47 \pm 1.41^{\mathrm{bc}}$ & $0.76 \pm 0.30^{\mathrm{b}}$ \\
\hline KN100 & $4.17 \pm 0.66^{\mathrm{a}}$ & $5.44 \pm 0.69^{\mathrm{a}}$ & $0.33 \pm 0.13^{\mathrm{ab}}$ & $0.43 \pm 0.44 \mathrm{a}$ & $4.83 \pm 2.39 \mathrm{ab}$ & $1.10 \pm 0.54 \mathrm{a}$ \\
\hline KN66 & $4.29 \pm 0.72^{\mathrm{a}}$ & $5.41 \pm 0.69^{\mathrm{a}}$ & $0.28 \pm 0.12^{\mathrm{b}}$ & $0.39 \pm 0.59 \mathrm{a}$ & $5.24 \pm 3.57 \mathrm{a}$ & $1.21 \pm 0.80 \mathrm{a}$ \\
\hline KN33 & $4.21 \pm 0.74^{\mathrm{a}}$ & $5.53 \pm 0.81^{\mathrm{a}}$ & $0.33 \pm 0.14^{\mathrm{ab}}$ & $0.28 \pm 0.39 \mathrm{a}$ & $3.80 \pm 1.70 \mathrm{abc}$ & $0.88 \pm 0.40 \mathrm{ab}$ \\
\hline \multicolumn{7}{|l|}{ GRM } \\
\hline 1 & $4.04 \pm 0.64^{\mathrm{a}}$ & $5.47 \pm 0.71^{\mathrm{a}}$ & $0.35 \pm 0.13^{\mathrm{a}}$ & $0.25 \pm 0.32^{\mathrm{a}}$ & $3.45 \pm 1.48^{\mathrm{a}}$ & $0.80 \pm 0.36^{\mathrm{a}}$ \\
\hline 2 & $4.16 \mathrm{v} 0.74^{\mathrm{a}}$ & $5.70 \pm 0.76^{\mathrm{a}}$ & $0.38 \pm 0.17^{\mathrm{a}}$ & $0.40 \pm 0.43^{\mathrm{a}}$ & $4.09 \pm 2.51^{\mathrm{a}}$ & $0.92 \pm 0.56^{\mathrm{a}}$ \\
\hline 3 & $4.25 \pm 0.75^{\mathrm{a}}$ & $5.60 \pm 0.85^{\mathrm{a}}$ & $0.33 \pm 0.16^{\mathrm{a}}$ & $0.37 \pm 0.47^{\mathrm{a}}$ & $3.95 \pm 2.69^{\mathrm{a}}$ & $0.89 \pm 0.62^{\mathrm{a}}$ \\
\hline
\end{tabular}

Msalts=mineral salts; GR=growth regulators; PHF=plant height in February, PHJ=plant height in Jun, MGR H, S, L, R=monthly rate of increase (in height, shoots, leaves and root), NSF=number of shoots in February, NSJ=number of shoots in June, $\mathrm{NLF}=$ number of leaves in February, $\mathrm{NLJ}=$ number of leaves in June, NRF=number of roots in February, and NRJ=number of roots in June.

In each column, the values with the same letter are not significantly different (Tukey test, $\mathrm{P}<0.05$ ); mean \pm standard deviation.

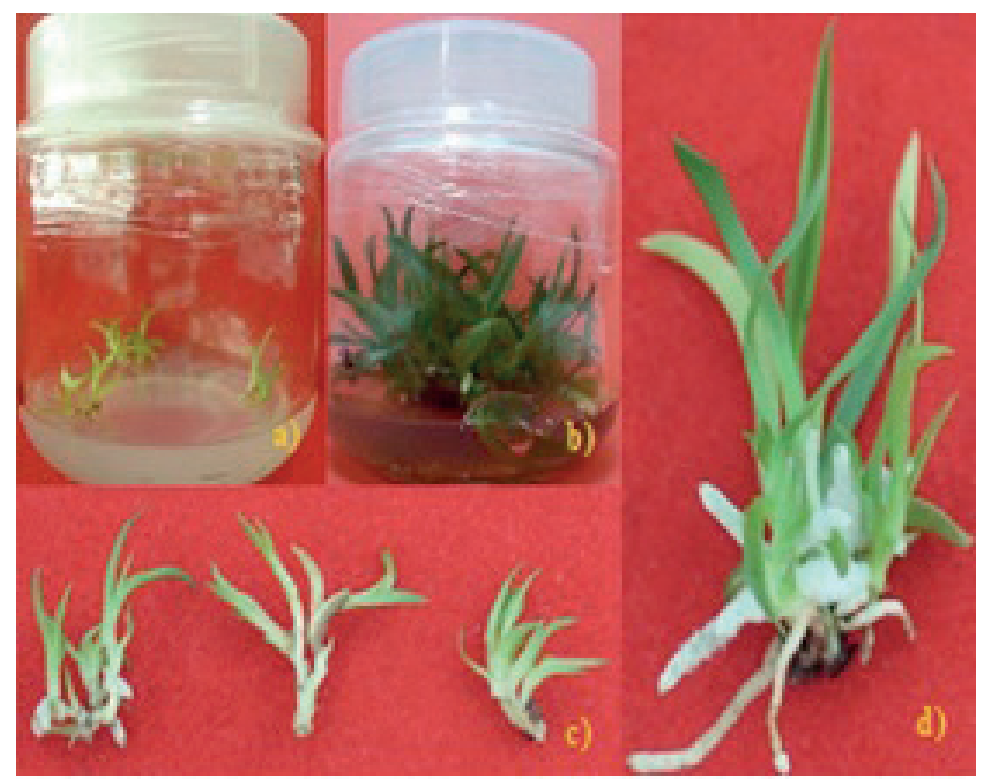

Figure 1. In vitro propagation of Laelia halbingeriana; a) plants at the beginning of the experiment; b) plants at the end of the experiment in T16; c) groups of three plants at the beginning and d) height and roots at the end of the experiment; treatment with KN66\% + GRM1. 
These values were significantly higher (Tukey, $0.05)$ than 0.58 to 0.78 roots/month formed by the plants grown in MS-100, MS-66 and MS-33 media (Tables 2 and 3).

The plants established in culture media with mineral salts MS-100 or MS-66 grew slowly; these media had 104.92 and $69.2 \mathrm{meq} \mathrm{L}^{-1}$ total ions, respectively (Table 4). These data indicate that when the number of ions is relatively high, the growth of L. halbingeriana is inhibited.

Regression analysis was used for additional description of the plant growth intensity during 120 days of incubation (Figure 2) as a function of the conditions of the growth culture medium (Table 5). The data indicate that the plants in $\mathrm{T} 4(\mathrm{KN}-100+0.5 \mathrm{mg}$
$\left.\mathrm{L}^{-1} \mathrm{BAP}+0.5 \mathrm{mg} \mathrm{L}^{-1} \mathrm{KIN}+0.5 \mathrm{mg} \mathrm{L}^{-1} \mathrm{IAA}\right)$ had higher growth rate than the plants established in $\mathrm{T} 1$ (MS-100 + $0.5 \mathrm{mg} \mathrm{L}^{-1} \mathrm{BAP}+0.5 \mathrm{mg} \mathrm{L}^{-1} \mathrm{KIN}+0.5$ $\mathrm{mg} \mathrm{L} \mathrm{L}^{-1} \mathrm{IAA}$ ); the amount of total ions was the only difference between these treatments. The growth in height of L. halbingeriana during 120 days was fit to a logarithmic model. The logarithmic equation for estimating the height showed a suitable goodness of fit $\left(\mathrm{R}^{2} \geq 0.96\right)$ and mean square of the error $\leq 0.43$, and the regression parameters $\beta_{0}$ and $\beta_{1}$ were highly significant $(P \leq 0.01)$.

The plants subjected to the best treatments $(4,5$, 6 and 11), which included mineral salts KN-100 or KN-66, grew faster than the plants subjected to the treatments with the culture medium with MS-100 mineral salts (Figure 2).

Table 3. Propagule size of Laelia halbingeriana grown for four months in the culture media with various types and concentrations of inorganic salts (Msalts) and mixtures of growth regulators (GRM).

\begin{tabular}{lcccc}
\hline $\begin{array}{l}\text { Treatment } \\
\text { Msalts-GRM }\end{array}$ & $\begin{array}{c}\text { Height } \\
(\mathrm{cm})\end{array}$ & Number of shoots & Number of leaves & Number of roots \\
\hline 1) MS100-GRM1 & $1.60 \mathrm{c}$ & $1.81 \mathrm{c}$ & $5.55 \mathrm{a}$ & $2.32 \mathrm{~b}$ \\
2) MS100-GRM2 & $1.55 \mathrm{c}$ & $1.86 \mathrm{c}$ & $5.67 \mathrm{a}$ & $2.64 \mathrm{ab}$ \\
3) MS100-GRM3 & $1.56 \mathrm{c}$ & $1.85 \mathrm{c}$ & $5.62 \mathrm{a}$ & $2.57 \mathrm{ab}$ \\
4) MS66-GRM1 & $1.67 \mathrm{bc}$ & $2.57 \mathrm{bc}$ & $5.68 \mathrm{a}$ & $2.95 \mathrm{ab}$ \\
5) MS66-GRM2 & $1.62 \mathrm{c}$ & $2.62 \mathrm{bc}$ & $5.80 \mathrm{a}$ & $3.27 \mathrm{ab}$ \\
6) MS66-GRM3 & $1.63 \mathrm{c}$ & $2.61 \mathrm{bc}$ & $5.75 \mathrm{a}$ & $3.20 \mathrm{ab}$ \\
7) MS33-GRM1 & $1.77 \mathrm{abc}$ & $2.94 \mathrm{bc}$ & $5.68 \mathrm{a}$ & $3.28 \mathrm{ab}$ \\
8) MS33-GRM2 & $1.72 \mathrm{abc}$ & $2.99 \mathrm{bc}$ & $5.80 \mathrm{a}$ & $3.60 \mathrm{ab}$ \\
9) MS33-GRM3 & $1.73 \mathrm{abc}$ & $2.98 \mathrm{bc}$ & $4.64 \mathrm{ab}$ \\
10) KN100-GRM1 & $2.18 \mathrm{a}$ & $6.63 \mathrm{a}$ & $5.75 \mathrm{a}$ & $4.96 \mathrm{ab}$ \\
11) KN100-GRM2 & $2.13 \mathrm{ab}$ & $6.68 \mathrm{a}$ & $5.38 \mathrm{a}$ & $4.89 \mathrm{ab}$ \\
12) KN100-GRM3 & $2.14 \mathrm{ab}$ & $6.67 \mathrm{a}$ & $5.50 \mathrm{a}$ & $5.05 \mathrm{ab}$ \\
13) KN66-GRM1 & $2.18 \mathrm{a}$ & $5.46 \mathrm{ab}$ & $5.45 \mathrm{a}$ & $5.37 \mathrm{a}$ \\
14) KN66-GRM2 & $2.13 \mathrm{ab}$ & $5.51 \mathrm{ab}$ & $5.35 \mathrm{a}$ & $5.30 \mathrm{ab}$ \\
15) KN66-GRM3 & $2.14 \mathrm{ab}$ & $5.50 \mathrm{ab}$ & $5.47 \mathrm{a}$ & $3.61 \mathrm{ab}$ \\
16) KN33-GRM1 & $1.98 \mathrm{abc}$ & $3.62 \mathrm{abc}$ & $5.42 \mathrm{a}$ & $3.93 \mathrm{ab}$ \\
17) KN33-GRM2 & $1.92 \mathrm{abc}$ & $3.67 \mathrm{abc}$ & $5.47 \mathrm{a}$ & $3.86 \mathrm{ab}$ \\
18) KN33-GRM3 & $1.94 \mathrm{abc}$ & $3.66 \mathrm{abc}$ & $5.59 \mathrm{a}$ & $5.54 \mathrm{a}$ \\
\hline
\end{tabular}

Table 4. Mineral composition ( $\mathrm{meq} \mathrm{L}^{-1}$ ) of the MS and KN nutrient solutions used for in vitro culture of Laelia halbingeriana.

\begin{tabular}{lcccccc}
\hline IC & $\begin{array}{c}\text { MS-100/meq L } \\
\text { I=OP }(\mathrm{MPa})\end{array}$ & $\begin{array}{c}\text { MS-66/meq L } \\
\text { I=OP }(\mathrm{MPa})\end{array}$ & $\begin{array}{c}\mathrm{MS}-33 / \mathrm{meq} \mathrm{L}^{-1}= \\
\mathrm{OP}(\mathrm{MPa})\end{array}$ & $\begin{array}{c}\mathrm{KN}-100 / \mathrm{meq} \mathrm{L}^{-1}= \\
\mathrm{OP}(\mathrm{MPa})\end{array}$ & $\begin{array}{c}\mathrm{KN}-66 / \mathrm{meq} \mathrm{L}^{-1}= \\
\mathrm{OP}(\mathrm{MPa})\end{array}$ & $\begin{array}{c}\mathrm{KN}-33 / \mathrm{meq} \mathrm{L}^{-1}= \\
\mathrm{OP}(\mathrm{MPa})\end{array}$ \\
\hline A & 52.46 & 34.60 & 18.90 & 27.96 & 18.45 & 9.22 \\
$\mathrm{C}$ & 52.47 & 34.60 & 18.05 & 27.96 & 18.45 & 9.22 \\
TI & $104.92=-0.23$ & $69.2=-0.15$ & $36.1=-0.08$ & $55.92=-0.12$ & $36.90=-0.08$ & $18.44=-0.04$ \\
\hline
\end{tabular}

IC: ion concentration; A: anions; C: cations: TI: total ions. MS: Murashige and Skoog; KN: Knudson; OP: osmotic potential. 
The analysis of variance and comparison of the means describe the responses of each variable individually thus limiting the selection of the best condition for quality plant development. The results obtained with the cluster analysis were useful for identification of the most appropriate culture medium conditions for rapid development of the quality plants by simultaneously varying several plant characteristics. The cluster analysis used an array of five variables recorded over
120 days including the monthly growth rate. At a distance of 4.89, two main groups, A and $\mathrm{B}$, and their subgroups were identified. Group A included the plants that had the best growth; all of which were cultured in $\mathrm{KN}$ mineral salt media, while group B included all plants cultured in MS media at any concentration and the plants in the culture media with KN-33 mineral salts. The plants with the slowest growth were maintained in the culture medium with the mineral

Table 5. Parameters of the logarithmic regression model of vertical growth of Laelia halbingeriana plants established in 18 different culture media.

\begin{tabular}{lccccccccc}
\hline Treat & $\mathrm{R}_{\text {adj }}^{2}$ & MSRE & $\boldsymbol{\beta}_{0}$ & $\boldsymbol{\beta}_{1}$ & Treat & $\mathrm{R}_{\text {adj }}^{2}$ & MSRE & $\boldsymbol{\beta}_{0}$ & $\boldsymbol{\beta}_{1}$ \\
\hline 1 & 0.97 & 0.22 & $1.28^{* *}$ & $0.25^{* *}$ & 10 & 0.97 & 0.27 & $1.21^{* *}$ & $0.44^{* *}$ \\
2 & 0.99 & 0.11 & $1.12^{* *}$ & $0.30^{* *}$ & 11 & 0.96 & 0.35 & $1.16^{* *}$ & $0.55^{* *}$ \\
3 & 0.97 & 0.24 & $1.17^{* *}$ & $0.31^{* *}$ & 12 & 0.97 & 0.23 & $1.17^{* *}$ & $0.34^{* *}$ \\
4 & 0.97 & 0.30 & $1.22^{* *}$ & $0.57^{* *}$ & 13 & 0.99 & 0.43 & $1.07^{* *}$ & $0.26^{* *}$ \\
5 & 0.96 & 0.33 & $1.27^{* *}$ & $0.45^{* *}$ & 14 & 0.98 & 0.20 & $1.12^{* *}$ & $0.38^{* *}$ \\
6 & 0.97 & 0.28 & $1.20^{* *}$ & $0.50^{* *}$ & 15 & 0.97 & 0.27 & $1.21^{* *}$ & $0.36^{* *}$ \\
7 & 0.99 & 0.13 & $1.16^{* *}$ & $0.26^{* *}$ & 16 & 0.98 & 0.21 & $1.23^{* *}$ & $0.45^{* *}$ \\
8 & 0.98 & 0.18 & $1.25^{* *}$ & $0.26^{* *}$ & 17 & 0.96 & 0.34 & $1.20^{* *}$ & $0.47^{* *}$ \\
9 & 0.97 & 0.23 & $1.12^{* *}$ & $0.38^{* *}$ & 18 & 0.97 & 0.28 & $1.18^{* *}$ & $0.45^{* *}$ \\
\hline
\end{tabular}

Treat: treatment. $\mathrm{R}_{\text {adj }}^{2}$ : adjusted regression coefficient; MSRE: mean square root of error; $\beta_{0,1}=$ parameters of the regression model. ${ }^{* *}$ : highly significant (t-Student, $\left.\mathrm{P} \leq 0.01\right)$.

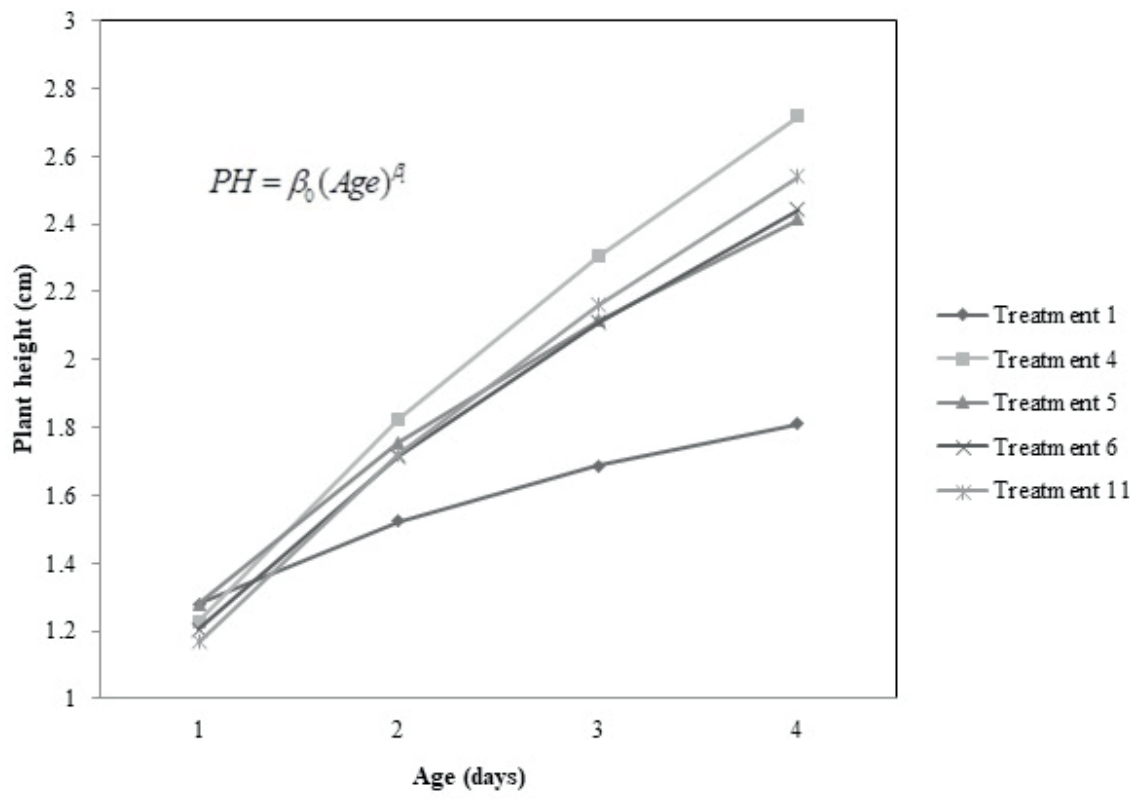

Figure 2. Vertical growth (PH) of Laelia halbingeriana plants cultured in vitro for four months under the conditions that produced significant effects. 


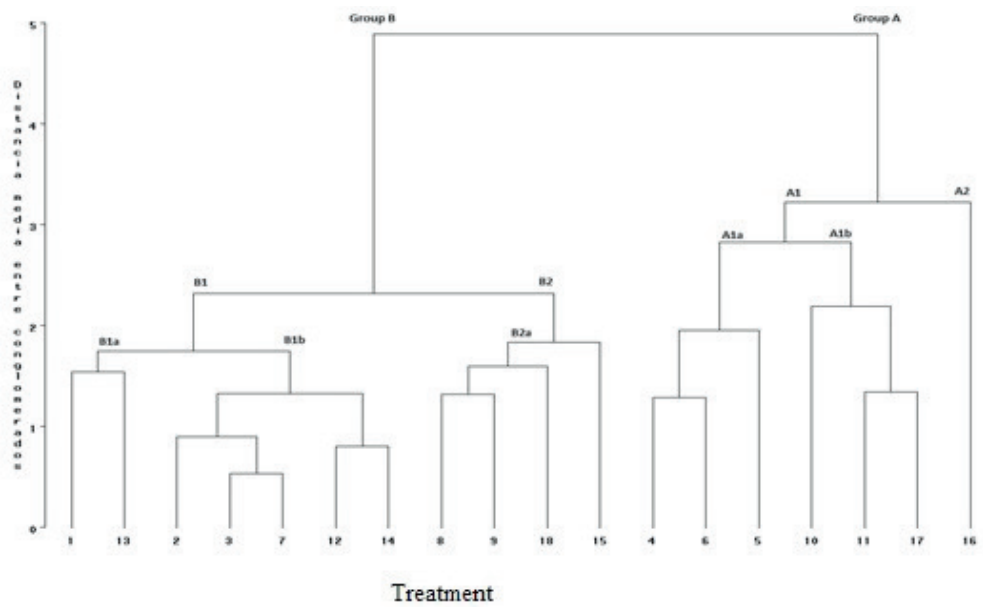

Figure 3. Cluster analysis of the variables and growth rates. Letters A and B represent the main groups; letters with the numbers represent the subgroups formed within each of the main groups (treatments numbering is described in to Table 3 ).

salts MS at $100 \%(\mathrm{~T} 1, \mathrm{~T} 2$ and $\mathrm{T} 3)$ as shown on the far left of the dendrogram (Figure 3); the conditions can be improved to yield the plants with better growth culminating in KN 100 (T16, $\mathrm{T} 17$ and T18) (treatment numbering refers to description of Table 3).

\section{Discussion}

This study demonstrates that the growth of the $L$. halbingeriana plants is influenced by the type and concentration of mineral salts to a greater extent than it is by the effects of GR. Thus, it is necessary to evaluate not only GR but also mineral salts and other components of the culture medium. Ferreira et al (2011) reported differences in propagule growth in Dendrobium due to the effect of various quantities of sucrose in the culture medium.

Plants established in the Knudson (1946) media

Orchid growth depends on the concentrations of solutes present in the culture medium. In this study, the plants that had faster growth were established in KN media similar to the results of Rodrigues et al. (2009) who found that Cattleya loddigesii (Lindl.) plants established in
$\mathrm{KN}-200 \%$ had faster growth and the plants in $\mathrm{KN}-100 \%$ achieved better shoot proliferation. Seeds of Cyrtopodium saintlegerianum (Carlosde Sousa et al., 2017) cultured in the media with $\mathrm{KN}$ mineral salts had a higher germination rate $(80 \%)$ at seven days, and the plants grew taller and had longer shoots than the plants grown in the culture media with MS salts.

Culture media with $\mathrm{KN}-100 \%$ influence seed germination and later plant growth. Ferreira and Suzuki (2008) found that the KN culture medium improved Hadrolaelia tenebrosa (Rolfe) Chiron \& V.P. Castro seed germination. In the case of Cyrtopodium saintlegerianum Rchb.f seeds established in KN media (Afraire et al., 2015), Cattleya (Lindl.) seeds in MS culture media (Schneiders et al., 2012), Coelogyne flaccida (Lindl.) and Dendrobium lasianthera J.J.Sm, shoot development occurred in the culture media with Vacin and Went mineral salts complemented with $2 \mathrm{~g}$ $\mathrm{L}^{-1}$ peptone (Utami et al., 2017).

Plants established in the Murashige and Skoog (1962) media

Plants grown in the culture medium with MS-66\% mineral salts achieved better values in most of 
the variables, except the number of leaves, than plants grown in the culture media with MS-100\%. The formulation MS-100 has 1.51 and 1.87 times more total ions than the formulations MS- $66 \%$ and $\mathrm{KN}-100 \%$. These results agree with the study of Sabarimuthan et al. (2013), who reported that Eulophia cullenii (Wight) B1. grew vigorously and produced roots in the media with MS diluted by half. In the case of propagation of Cyrtopodium brandonianum Barb.Rodr (Flachsland et al., 2011) and Cymbidium bicolor Lindl. (Mahendran \& Bai, 2012), the plants established in the culture media with diluted MS mineral salts grew faster and had more roots than the plants grown in the culture medium with MS at full concentration. In propagation of $D$. densiflorum Lindl. ex Wall. (Jian-Ping et al., 2008) development of protocormlike bodies (PLB) of Cymbidium aloifolium (L.) Sw. and Dendrobium nobile (Nayak et al., 2001), the growth of the propagules was better in the case of a combined effect of the MS mineral salts and BAP.

Shoot and rhizome development of Geodorum densiflorum was obtained in culture media with MS mineral salts and BAP (Roy \& Banerjee, 2001). Formation of the pseudobulbs of Cymbidium finlaysonianum Lindl. was stimulated in the culture media with MS mineral salts supplemented with 1.0 to $1.5 \mathrm{mg} \mathrm{L}^{-1} \mathrm{BAP}$; the culture medium with $0.75 \mathrm{mg} \mathrm{L}^{-1}$ NAA stimulated multiplication and size of the shoots (Islam et al., 2015). In Dendrobium, PLB were formed and later development of the shoots and rooting occurred in the culture medium with MS mineral salts and 44.4 $\mu \mathrm{MBAP}$ and 6.97 $\mu \mathrm{M}$ KIN (Martin \& Madassery, 2006), while Eulophia nuda Lindl. shoots multiplied when they were established in the culture media with MS and BAP (Dawande \& Gurav, 2015). The orchid Laelia halbingeriana grows slowly, and the results of our study suggest that it is possible to accelerate plant growth by modifying not only GR but also the mineral salt composition.

The culture media with KN 100\% and KN 66\% mineral salts have a total ions of 55.92 and 36.90 meq $\mathrm{L}^{-1}$, which correspond to the osmotic potentials, OP, of -0.122 and $-0.080 \mathrm{MPa}$; the plants grew better in these media than the plants cultured in media with MS 100\% mineral salts. The data reported by Cárdenas and Villegas (2002) show that an increase in the concentration of solutes results in more negative osmotic potential of the culture medium and therefore plant growth is inhibited. The MS inorganic salts at $100 \%$ concentration generate an $\mathrm{OP}$ of $-0.23 \mathrm{MPa}$, and $30 \mathrm{~g} \mathrm{l}^{-1}(87.7 \mathrm{mM})$ of sucrose generates an OP of $-0.45 \mathrm{MPa}$; the combination of these factors in the culture medium creates an OP of $-0.68 \mathrm{MPa}$ (Miguel-Luna et al., 2014).

The models of logarithmic regression that describe vertical plant growth as a function of time show that the plants in the T16 culture medium had an average growth rate of $0.25 \mathrm{~cm} /$ month during 120 days of incubation. The orchids grew slowly, and the nonlinear regression models were useful for describing their growth and predicting the behavior of the species (Rodríguez-Ortiz et al., 2012). The logarithmic fit model describing the vertical growth during 120 days has a suitable goodness of fit $\left(R^{2} \geq 0.96\right)$. The regression models are useful for describing and predicting growth over a given time; thus, these models are frequently used for forest species in the field (Santiago-García et al., 2015). However, these models are also useful for description of the behavior of the in vitro cultures of Laelia halbingeriana.

The type and concentration of mineral salts is an important condition to improve in vitro growth of Laelia halbingeriana plants. Culture media with Knudson (1946) mineral salts provided better conditions for plant growth compared to those obtained in the culture media with Murashige and Skoog mineral salts. The plants established in the culture media with inorganic Knudson salts at 100 and $66 \%$ supplemented with $0.5 \mathrm{mg} \mathrm{L}^{-1} \mathrm{BAP}$, $0.5 \mathrm{mg} \mathrm{L}^{-1} \mathrm{KIN}$ and $0.5 \mathrm{mg} \mathrm{L}^{-1} \mathrm{IAA}$ showed faster growth and development. The mixtures of the GR did not have differential effects on the growth and development of Laelia halbingeriana. 


\title{
Resumen
}

\begin{abstract}
R. García-González, J.R. Enríquez-del Valle, G. Rodríguez Ortiz, G.V. Campos-Angeles, E.A. Pérez-García, y J. Ruiz-Luna. 2020. Sales minerales y reguladores de crecimiento para la micropropagación de Laelia halbingeriana Salazar \& Soto Arenas. Int. J. Agric. Nat. Resour. 105-116. Laelia halbingeriana es una orquídea epífita silvestre, endémica de Oaxaca, México, colectada sin planes de manejo, y este trabajo tuvo el objetivo de propagar y evaluar el desarrollo in vitro de esta especie en medios de cultivo que variaron en sales minerales y reguladores de crecimiento. Grupo de 3 plantas de 1.2 a $1.4 \mathrm{~cm}$ de altura se establecieron en cada frasco con medios de cultivo que tenian $30 \mathrm{~g} \mathrm{~L}^{-1}$ de sacarosa, $1 \mathrm{mg} \mathrm{L}^{-1}$ de tiamina, $100 \mathrm{mg} \mathrm{L}^{-1}$ de inositol y $0.5 \mathrm{mg} \mathrm{L}^{-1}$ de bencilaminopurina, BAP, variando las sales minerales de Murashige y Skoog (1962) o Knudson (1946) (100, 66 y 33\%) los reguladores de crecimiento: ácido indolacético, AIA, y kinetina, Kin, y su concentración $\left(0.5+0.5 \mathrm{mg} \mathrm{L}^{-1}\right.$, $1+1 \mathrm{mg} \mathrm{L}^{-1}$ y $\left.2+2 \mathrm{mg} \mathrm{L}^{-1}\right)$. El pH se ajustó a 5.8, y agregó $5.5 \mathrm{~g} \mathrm{~L}^{-1}$ de agar. Transcurridos 120 días de incubación, las plantas que estuvieron en medios Knudson 100 y $66 \%$, tuvieron 2.1 de altura y 4.8 raíces, mientras las plantas en medios Murashige y Skoog $100 \%$ tuvieron 1.5 de altura y 2.5 raíces. Durante 120 días, las plantas mostraron crecimiento en altura con una tendencia logarítmica $\left(R^{2} \geq 0.96\right)$. Al evaluar simultáneamente varias características de plantas mediante análisis clúster, se determinó que el mejor medio de cultivo para el desarrollo de Laelia halbingeriana tenía las sales minerales Knudson al 100\%, $0.5 \mathrm{mg} \mathrm{L}^{-1}$ de BAP, $0.5 \mathrm{mg} \mathrm{L}^{-1}$ de AIA, $0.5 \mathrm{mg} \mathrm{L}^{-1}$ de KIN.
\end{abstract}

Palabras clave: Desarrollo, propagación, reguladores de crecimiento, sales minerales.

\section{References}

Afraire, R. L., Borges-de Paiva, N. V., Galdi, B. A., Fernanda-de Oliveira, J., Torrezan, M. A., Ferreira-de Lima, S., \& Campos, O. W. (2015). In vitro propagation of Cyrtopodium saintlegerianum rchb. f. (orchidaceae), a native orchid of the Brazilian savannah. Crop Breeding and Applied Biotechnology, 15:10-17. http://dx.doi. org/10.1590/1984-70332015v15n1a2.

Avila-Díaz, I., Sarabia-Ochoa, M. E., Carlos-Gómez, A., \& Salgado-Garciglia, R. (2010). Callus growth and plant regeneration in Laelia speciosa (Orchidaceae). Lankesteriana, 10(1):13-18. https://doi.org/10.15517/lank.v10i1.18319.

Cárdenas, L. A., \& Villegas, M. A. (2002). Potencial osmótico del medio de cultivo con diferentes componentes para la propagación in vitro. Revista Fitotecnia Mexicana, 25(2):213-217.

Carlos-de Sousa, S., Garcês de Araújo, L., Inácio, S. K. C., Mota, S. D., Tadeu, S. S., \& Faria, E.
P. R. (2017). Germinação e desenvolvimento in vitro de orquídea epífita do Cerrado. Ornamental Horticulture, 23(1):96-100. http://dx.doi. org/10.14295/oh.v23i1.923.

Dalzotto, A. C. (2013). Efecto de medios de cultivo en el crecimiento in vitro de Oncidium bifolium SIMS. FEDERAL. Revista Cientifica Agropecuaria, 17(1-2):7-15.

Dawande, V., \& Gurav, R. (2015). In-vitro seed germination and effect of growth regulators on subsequent development of protocorms of Eulophia nuda LINDL. International Journal of Applied Sciences and Biotechnology, 3(2):243-247. DOI: 10.3126/ijasbt.v3i2.12476.

Ferreira, W. D. M., Suzuki, R. M., Pescador, R., Figueiredo-Ribeiro, R.C.L., \& Kerbauy, G. B. (2011). Propagation, growth, and carbohydrates of Dendrobium Second Love (Orchidaceae) in vitro as affected by sucrose, light, and dark. In Vitro Cellular \& Developmental Biology-Plant, 47:420-427. 10.1007/s11627-010-9311-x. 
Ferreira, W. M., \& Suzuki, R. M. (2008). O cultivo in vitro de orquídeas como alternativa para a preservação de espécies nativas ameaçadas de extinção. In Loiola, M.I.B., Baseia, I.G. \& Lichston, J.E. (eds) Atualidades, desafios e perspectiva da botânica no Brasil. Natal, Imagem Gráfica, pp. 67-68.

Flachsland, E., Terada, G., Fernández, J. M., Medina, R., Schinini, A., Rey, H., \& Mroginski, L. (2011). Plant regeneration from root-tip culture of Cyrtopodium brandonianum Barb. Rodr. (Orchidaceae). Propagation of Ornamental Plants, 11:184-188.

Flores-Escobar, G. J., Legaria-Solano, P. I., GilVásquez, I., \& Colinas-León, M. T. (2008). Propagación in vitro de Oncidium stramineum Lindl., una orquídea amenazada y endémica de México. Revista Chapingo. Serie Horticultura, 14(3):347-353. http://dx.doi.org/10.5154/r. rchsh.2007.02.009.

Hágsater, E., Soto-Arenas, M. A., Salazar-Chávez, G. A., Jiménez-Machorro, R., López-Rosas, M. A., \& Dressler, R. L. (2006). Las orquídeas de México. Acta Botánica Mexicana 75: 101-103. https://doi.org/10.21829/abm75.2006.1132

Heredia-Rincón, A., Enríquez-del Valle, J. R., Zúñiga, F. M., Campos-Ángeles, G. V., \& VelascoVelasco, V. A. (2009). Propagación in vitro y aclimatación ex vitro de Laelia halbingeriana. Acta Horticulturae, 843. 10.17660/ActaHortic.2009.843.24.

Hossain, M. M., Sharma, M., Teixeira-da Silva, J. A., \& Pathak, P. (2009). Seed germination and tissue culture of Cymbidium giganteum Wall. ex Lindl. Scientia Horticulturae, 123:479-487. 10.1016/j. scienta.2009.10.009.

INEGI. (2004). Cuaderno Estadistico Municipal Gobierno del Estado de Oaxaca. México. pp. 3-5.

Islam, S. M. S., Islam, T., Bhattacharjee, B., Mondal, T. K., \& Subramaniam, S. (2015). In vitro pseudobulb based micropropagation for mass development of Cymbidium finlaysonianum Lindl. Emirates Journal of Food and Agriculture, 27(6):469-474. 10.9755/ejfa.2015.04.017.

Jian-Ping, L., Ying, W., Xue-Qiang, Z., \& Li, H. (2008). Micropropagation of Dendrobium den- siflorum Lindl. ex Wall. through protocorm-like bodies: effects of plant growth regulators and lanthanoids. Plant Cell, Tissue and Organ Culture, 93(3):333-340. 10.1007/s11240-008-9381-1.

Lozano-Rodríguez, M. A., Menchaca-García, R. A., Alanís-Méndez, J. L., \& Pech-Canché, J. M. (2015). Cultivo in vitro de yemas axilares de $\mathrm{Va}$ nilla planifolia Andrews con diferentes citocininas. Revista Científica Biológico Agropecuaria Tuxpan, 4(6):1153-1165.

Mahendran, G., \& Bai, V. N. (2012). Direct somatic embryogenesis and plant regeneration from seed derived protocorms of Cymbidium bicolor Lindl. Scientia Horticulturae, 135:40-44. 10.1016/j. scienta.2011.12.003.

Martin, K. P., \& Madassery, J. (2006). Rapid in vitro propagation of Dendrobium hybrids through direct shoot formation from foliar explants, and protocorm-like bodies. Scientia Horticulturae, 108:95-99. 10.1016/j.scienta.2005.10.006.

Murashige, T., \& Skoog, F. (1962). A revised medium for rapid growth and biossays whith tobacco tissue cultures. Physiolog Plant, 15:473497. https://doi.org/10.1111/j.1399-3054.1962. tb08052.x.

Nayak, N. R., Sahoo, S., Patnaik, S., \& Rath, S. P. (2001). Establishment of thin cross section (TCS) culture method for rapid micropropagation of Cymbidium aloifolium (L.) Sw. and Dendrobium nobile Lindl. (Orchidaceae). Scientia Horticulturae, 94:107-116. https://doi.org/10.1016/ S0304-4238(01)00372-7.

Rodrigues, S. J. D., Gomes-de Araújo, A., Pasqua, M., Almendagna, R. F., \& Aparecida-de Assis, F. (2009). Concentrações de sais do meio Knudson $\mathrm{C}$ e de ácido giberélico no crescimento in vitro de plântulas de orquídea. Ciência Rural, 39(3):772-777. http://dx.doi.org/10.1590/ S0103-84782009000300021.

Rodríguez-Ortiz, G., De Los Santos-Posadas, H. M., González-Hernández, V. A., Aldrete, A., GómezGuerrero, A., \& Fierros-González, A. M. (2012). Modelos de biomasa aérea y foliar en una plantación de pino de rápido crecimiento en Oaxaca. Madera y Bosques, 18(1):25-41. https://doi. org/10.21829/myb.2012.1811116. 
Sabarimuthan, W. D., Reny, N., Shylajakumari, S., \& Krishnan, P. (2013). In vitro propagation and field establishment of Eulophia cullenii (Wight) B1., a critically endangered orchid of Western Ghats, India through culture of seeds and axenic seedling-derived rhizomes. In vitro Cellular and Developmental Biology-Plant, 49(5):520-528. 10.1007/s11627-013-9521-0.

Salazar, G. A., Reyes-Santiago, G., Brachet, C., \& Pérez-Crisanto, J. (2006). Orquídeas y otras plantas nativas de la Cañada Cuicatlán, Oaxaca, México. Boletín de la Sociedad Botánica de México, 79:93-95.

Salazar, G.A., Jiménez-Machorro, R., Huerta, H. M., \& Hágsater, E. (2014). A new species and a new natural hybrid of Laelia (Orchidaceae) from Oaxaca, Mexico. Phytotaxa, 178(1): 161-170. http://dx.doi.org/10.11646/phytotaxa.178.3.1

Santiago-García, W., De los Santos-Posadas, H. M., Ángeles-Pérez, G., Valdez-Lazalde, J. R., CorralRivas, J. J., Rodríguez-Ortiz, G., \& SantiagoGarcía, E. (2015). Whole-stand growth and yield models for Pinus patula. Madera y Bosques, 21(3):95-110.

SAS Institute Inc. (2004). SAS/STAT 9.1 User's Guide. SAS Institute, Cary, NC. USA. 4979 p.

Schneiders D., Pescador, R., Raitz, B. M., \& Mamoru, S. R. (2012). Germinação, crescimento e desenvolvimento in vitro de orquídeas (Cattleya spp., Orchidaceae). Ceres Vicosa, 59(2):185-191. http://dx.doi.org/10.1590/ S0034-737X2012000200006.

Suárez-Quijada, I., Hernández-Altamirano, M., Chávez-Ávila, V. M., Sandoval-Zapotitlán, E., \& Martínez-Palacios, A. (2007). Propagación in vitro y aclimatación de Euchile mariae (AMES) Withner (Orchidaceae). Lankesteriana Interntional Journal on Orchidology, 7(1-2):388-393. https://doi.org/10.15517/lank.v7i1-2.19609.

Utami, E. S. W., Hariyanto, S., \& Manuhara, Y. S. W. (2017). In vitro propagation of the endangered medicinal orchid, Dendrobium lasianthera J.J.Sm through mature seed culture. Asian Pacific Journal of Tropical Biomedicine, 7(5):406410. https://doi.org/10.1016/j.apjtb.2017.01.011. 